\title{
In-Vitro Evaluation of some Nutritive and Antioxidant Constituents of Oryctes Rhinoceros Larva
}

\author{
Egba Simeon I ${ }^{1,2 *}$. Anaduaka Emeka $\mathrm{G}^{1}$ Ogugua Vincent $\mathrm{N}^{1}$ And Durunna \\ Amarachi H. . \\ ${ }^{1}$ Department of Biochemistry, University of Nigeria, Nsukka, Nigeria \\ ${ }^{2}$ Department of Biochemistry, Michael Okpara University of Agriculture, Umudike, Nigeria
}

\begin{abstract}
This study was carried out to investigate some of the nutritional and antioxidant potentials of Oryctes rhinoceros larva. The proximate, vitamin and mineral analyses of the larva (dried) were investigated. The proximate analysis constitutes of fat (35.97\%), protein (33.97\%), carbohydrate $(19.31 \%)$ and fibre $(2.33 \%)$. Some of the vitamins present were vitamin A $(3.67 \mathrm{mg} / 100 \mathrm{~g})$, vitamin $C(0.49 \mathrm{mg} / 100 \mathrm{~g})$ and vitamin $E(0.42$ $\mathrm{mg} / 100 \mathrm{~g})$ while some of the mineral constituents analysed were iron $(3.42 \mathrm{mg} / 100 \mathrm{~g})$, calcium $(3.48 \mathrm{mg} / 100 \mathrm{~g})$ and zinc $(1.58 \mathrm{mg} / 100 \mathrm{~g})$. This result, suggests that the larva may be a good source of essential nutrients which could go a long way in helping to solve most nutritional related problems and diseases among the population that consume it and could form bases for new food/feed products of considerable nutritive value, in view of its high protein and vitamin A contents.
\end{abstract}

Key words: Oryctes rhinoceros, Vitamins, Antioxidant, Nutrients, Minerals.

\section{Introduction}

Malnutrition is one of the huge problems facing the world today especially the developing nations. Due to inadequate diets, a third of the world's children fail to reach their physical and mental potential and many are made vulnerable to infectious diseases that account for half of their deaths (WHO, 1992). In these regions, a single food stuff which could be a cereal or starchy food makes up $60-80 \%$ of the diet and food of animal origin is in short supply. The absence of suitable and acceptable protein supplements of high biological value that could be used for supplementary and mixed feeding of infants and young children and as part of the adult diet has been a major problem in developing countries (Okaraonye and Ikewuchi, 2009).

Insects have played an important part in the history of human nutrition in these developing regions like Africa, Asia and Latin America. (Fasunwon et al., 2011).They are traditional foods in most cultures and has many nutrients to offer. Ordinarily, they are not used as emergency food during shortages, but are included as a planned part of the diet throughout the year or when seasonally available (Okaraonye and Ikewuchi, 2009).They have been used as foods and to a large extent eaten as titbits or exclusively by children.

Among these insects is Oryctes rhinoceros, so called because of its resemblance to the rhino, and it is primarily a pest of coconut in most part of the world, especially Southern Asia, but in Africa, Nigeria in particular; it lives and feeds mostly on oil and raffia palms. While the adults attack the palm trees, the larvae are harmless, feeding only on decaying organic matter such as decaying palm logs, manures and rubbish dumps (Okaraonye and Ikewuchi, 2009).

The larvae are either smoked or fried and eaten in several parts of southern Nigeria, especially in Bayelsa, Delta, Edo and Anambra States, where active marketing of the fried grubs take place (Okaraonye and Ikewuchi, 2009). They are apparently highly nutritious and full of protein and may be consumed as part of a meal or as a complete meal. Base on these facts, this study is aimed at evaluating some of the nutritive constituents of Oryctes rhinoceros so as to ascertain its impact to the populace that consume it.

\section{Collection and identification of sample}

\section{Materials And Methods}

Live larvae of Oryctes rhinoceros were collected from dead oil and coconut palm tree trunks from Amaulu Mbieri in Mbaitoli Local Government Area of Imo State in Nigeria and were identified at the Department of Zoology, University of Nigeria Nsukka. The live Oryctes rhinoceros larvae were killed by slightly crushing the head using a clean stick. They were then sun dried for some weeks. The dried larvae were grinded and used for the analysis.

\section{PROXIMATE ANALYSIS}

Proximate analysis of the sample was carried out in triplicate, according to standard method (AOAC, 1999), in order to determine the moisture, crude protein, ash, crude fat and total carbohydrates. 


\section{DETERMINATION OF ASH CONTENT}

This was done following standard method by Association of Official Analytical Chemists (AOAC, $1999)$ and it's summarized as follows: A silica dish was heated at $600^{\circ} \mathrm{C}$, cooled and weighed. The sample $(2 \mathrm{~g})$ was transferred into the dish and weighed. The dish was placed in a muffle furnace and heated at $600^{\circ} \mathrm{C}$ in a furnace for $3 \mathrm{hrs}$ and allowed to cool. Percentage ash content was calculated using the formula below:

$\%$ Ash $=\frac{\text { weight of ash }}{\text { Weight of fresh sample }} \quad \frac{100}{1}$

\section{DETERMINATION OF PROTEIN CONTENT}

This was done using the micro-Kjeldahl method. Oven dried ground sample $(0.5 \mathrm{~g})$ was transferred into a $30 \mathrm{ml}$ kjeldahl flask carefully and $15 \mathrm{ml}$ conc. $\mathrm{H} 2 \mathrm{SO} 4$ was added. The catalyst (mixture of selenium oxide and $\left.\mathrm{CuSO}_{4}\right)(1 \mathrm{~g})$ was added. This was heated cautiously on digestion rack under fume hood until a clear greenish solution appears. After the digest has cleared, the mixture was heated for another 30 minutes and allowed to cool. About $10 \mathrm{ml}$ distilled water was added to avoid caking and then transferred to the Kjeldahl distillation apparatus. Ten millilitres (10mls) of $40 \% \mathrm{NAOH}$ were added to the mixture and allowed to distill. The distillate was later titrated to first pink colour with $0.01 \mathrm{M}$ HCL and the concentration of protein calculated using the formula as shown below:

$\%$ Nitrogen $=\underline{\text { Titre value } \times 14.1 \times 0.1 \times 100 \times 5}$

$1000 \times$ weight of sample

$\%$ Protein $=\%$ Nitrogen $\times 6.25$ (6.25 is a constant)

\section{DETERMINATION OF FATS AND OIL CONTENT}

This was done according to the method describe by AOAC (1999). An extraction flask was thoroughly washed and dried in hot oven for 30 minutes. It was placed in a dessicator to cool. Two grams $(2 \mathrm{~g})$ of the ground sample was weighed and transferred into clean filter paper and then placed inside the extractor thimble, which was put inside the soxhlet extractor. A known volume $(2 \mathrm{ml})$ of petroleum ether was added. The apparatus was set up and then heated and allowed to run for 4 hours. The ether was recovered at the end of the extraction before the thimble was removed. The oil collected in the flask was dried at $100^{\circ} \mathrm{C}$ in an oven and then weighed. The percentage $(\%)$ fat content was calculated using the following formula.
$\%$ fat $=$
$\underline{\mathrm{C}-\mathrm{B}} \mathrm{X}$
$\underline{100}$
A
1
A = weight of empty flask
$\mathrm{B}=$ weight of sample
$\mathrm{C}=$ weight of flask + oil after drying

\section{DETERMINATION OF FIBRE CONTENT}

This was done according to the method outlined by AOAC (1999) and is described as follows: Preheated $\mathrm{H} 2 \mathrm{SO} 4(150 \mathrm{mls})$ was added to $1.5 \mathrm{~g}$ of the ground extract and then heated for 30 minutes and then filtered. The residue was washed three times with hot water. To this was added $150 \mathrm{ml}$ pre-heated $\mathrm{KOH}$ and heated to boiling. Five (5) drops of anti-foaming agent was added, boiled slowly for 30 minutes and then filtered. The residue was washed three times with hot water and another three times with acetone. It was dried at $130^{\circ} \mathrm{C}$ for 1 hour, weighed (W2) and heated at $500^{\circ} \mathrm{C}$ and then weighed again (W3). Percentage fibre was calculated using the formula as shown below:

$\%$ fibre $=\frac{\mathrm{W} 2-\mathrm{W} 3}{\mathrm{~W} 1} \quad \mathrm{x} \quad \frac{100}{1}$

Where W1 = weight of ground sample used

$\mathrm{W} 2$ = weight of residue after drying at drying at $103^{\circ} \mathrm{C}$

$\mathrm{W} 3$ = weight of ash

\section{DETERMINATION OF MOISTURE CONTENT}

Two grams $(2 \mathrm{~g})$ of ground extract were dried to a constant weight at $600^{\circ} \mathrm{C}$ in a hot air circulating oven for 24 hours. The moisture content was calculated as the difference in weight after drying as shown below:

$$
\frac{\mathrm{W} 1-\mathrm{W} 2}{\mathrm{~W} 1} \quad \mathrm{X} \quad \frac{100}{1}
$$

Where W1 = weight of sample before drying

W2 = weight of sample after drying. 


\section{VITAMIN ANALYSIS}

\section{DETERMINATION OF VITAMIN C}

One gram (1g) of the sample was weighed and macerated with $20 \mathrm{~g}$ of $0.4 \%$ Oxalic acid and filtered, and $1 \mathrm{ml}$ of the filtrate was pipetted and $9 \mathrm{mls}$ of Indophenol reagent was added, then absorbance was measured at $520 \mathrm{~nm}$. Then concentration of Vitamin $\mathrm{C}$ was extrapolated from the standard curve.

\section{DETERMINATION OF VITAMIN A}

One gram $(1 \mathrm{~g})$ of the sample was weighed and macerated with $20 \mathrm{mls}$ of petroleum ether. It was evaporated to dryness and $0.2 \mathrm{ml}$ of chloroform acetic anhydride was added and $2 \mathrm{mls}$ of TCA chloroform were added and the absorbance measured at $620 \mathrm{~nm}$. Then concentration of vitamin A was extrapolated from the standard curve.

\section{DETERMINATION OF VITAMIN E}

One gram $(1 \mathrm{~g})$ of the sample was weighed and macerated with $20 \mathrm{mls}$ of ethanol. One milliliter (1ml) of $0.2 \%$ ferric chloride in ethanol was added, then $1 \mathrm{ml}$ of $0.5 \% \alpha, \alpha$-dipyridyl was also added, It was diluted to $5 \mathrm{mls}$ with distilled water and absorbance was measured at 520nm. Then concentration of Vitamin E was extrapolated from the standard curve.

\section{MINERAL ANALYSIS \\ PREPARATION OF SAMPLE}

Five grams $(5 \mathrm{~g})$ of the sample was weighed into a clean dried crucible and transferred to a multiple furnace. It was ashed at $700^{\circ} \mathrm{C}$ for 4 hours and cooled in a dessicator, then $5 \mathrm{mls}$ of $30 \% \mathrm{Hcl}$ and $15 \mathrm{mls}$ of distilled water were added and diluted to $50 \mathrm{mls}$ with distilled water.

\section{DETERMINATION OF ZINC CONTENT}

Five millilitres (5mls) of the ashed sample was pipette and $2 \mathrm{mls}$ of citric acid solution was added. Two (2) drops of phenolphthalein indicator was also added and it was neutralized with ammonia. Then, $0.1 \mathrm{ml}$ of ammonia in excess and $5 \mathrm{mls}$ of dithizone solution was added and shaked vigorously. The lower layer was discarded and $2 \mathrm{mls}$ of Carbon tetrachloride was added and shaked. The carbon tetrachloride layer was discarded and $5 \mathrm{mls}$ of dilute dithizone was added to the aqueous layer and shaked. The absorbance of the dithizone layer was measured at $532 \mathrm{~nm}$. Then concentration of zinc was extrapolated from the standard curve.

\section{DETERMINATION OF IRON CONTENT}

Five millilitres $(5 \mathrm{mls})$ of the sample was pipette and $1 \mathrm{ml}$ of hydroquinone was added. This was followed by the addition of $1.5 \mathrm{mls}$ of acetate buffer and $1 \mathrm{ml}$ of 0.17 dipyridyl and shaked, the absorbance was measured at $520 \mathrm{~nm}$.

\section{DETERMINATION OF CALCIUM CONTENT}

Ten millilitres (10mls) of the solution was pipette into $250 \mathrm{ml}$ flask and $25 \mathrm{mls}$ of $\mathrm{KOH}, 25 \mathrm{mls} \mathrm{of} \mathrm{H}_{2} \mathrm{O}$ and pinch of calcium indicator was added and it was titrated against EDTA $(0.01 \mathrm{~N})$ to an end point.

$\%$ Calcium $=$ volume of EDTA $\times$ mol. of EDTA $\times$ Atomic Wt. of Ca $\times 100 \times$ Dilution factor $1000 \mathrm{x}$ Weight of sample used $\mathrm{x}$ Aliquote

\section{PROXIMATE ANALYSIS}

\section{Results}

The fat content $(35.80 \%)$ and protein content $(33.97 \%)$ of the sample were higher than carbohydrate content $(19.31 \%)$ which was moderate in the sample and fiber $(2.33 \%)$ which was low while the moisture and ash contents were $5.55 \%$ and $3.01 \%$ respectively (Table 1 ).

\section{VITAMIN ANALYSIS}

The vitamin A content $(3.67 \mathrm{mg} / 100 \mathrm{~g})$ is the highest vitamin concentration in the sample. The concentration of vitamin C $(0.49 \mathrm{mg} / 100 \mathrm{~g})$ and vitamin $\mathrm{E}(0.42 \mathrm{mg} / 100 \mathrm{~g})$ were relatively low in the sample.

\section{MINERAL ANALYSIS}

The calcium content of the sample $(3.48 \pm 0.252 \mathrm{mg} / 100 \mathrm{~g})$ was the highest mineral concentration of the sample followed by the iron content $(3.42 \pm 0.003 \mathrm{mg} / 100 \mathrm{~g})$. Zinc $(1.58 \pm 0.003 \mathrm{mg} / 100 \mathrm{~g})$ was the list present among the minerals evaluated. 


\section{Discussion}

The proximate analysis of Oryctes rhinoceros larva is reported in Table 1. The crude protein content is higher than those reported for cow milk, egg, termite, beef, insects such as Rhynchophorus phoenicis, Zonocerus variegatus, Oryctes boas, Analeptes trifaciasta (FAO, 1992; Singh, 2004; Ekpo and Onigbinde, 2005; Ejidala et al., 2009), but lower than those for caterpillar, Imbrasia belina and locust (Mayhew and Penny, 1988; Fasunwon et al., 2011). The implication of this high protein content is that the larval meal can contribute significantly to the daily protein requirement of humans which is about 23-56 grams. It can help in combating protein deficiency and also in the development of the muscle, glands and tissues (Pyke,1979).The larva has higher total carbohydrate content compared to the reported values for cow milk, egg, Zonocerus variegatus, Macrotermes bellicocus, Analeptes trifasciata, caterpillar, termite and Rhynchophorus phoenicis (Singh, 2004; Ejidala et al., 2011).

From the energy point of view, carbohydrates represent the most valuable of the food component and the daily adult intake should be 500g/day (FAO, 1992). It also function as essential component of nucleic acid as seen in ribose. Therefore the specie can serve as a nutritive energy source for humans.

The moisture content is low but it is higher than that reported for dried caterpillar but lower than those for termite, cow milk, egg and Oryctes monoceros (FAO, 1992; Singh, 2004; Ekpo and Onigbinde, 2005; Ejidala et al., 2009). The low moisture content may be due to water lost during sun-drying. Moisture content of food is usually used as a measure of the stability and susceptibility to microbial contamination. Therefore dehydration would generally improve the shelf life/preservation of the larva and increase the other food components.

The fat content of the larva in this study was the highest. It was very high in view of the report by Ekpo (2011) on Imbrasia belina and Fasunwon et al., (2011) on Oryctes boas and Rhynchophorus phoenicis. Also when the result was compared to fats derived from conventional foods of animal origin (Pyke, 1979), it was found to be higher. Fat is the chief form in which energy is stored in insect larvae (Fasunwon et al., 2011). It is usually greater in large amount of mature larvae before metamorphosis. The fat content of this larva could have contributed to its highly acceptable flavor when fried or roasted.

Though the crude fiber observed in this study was low, yet it is higher than the values reported by Fasunwon et al., (2011) for insects such as Oryctes boas and Rhyncophorus phoenicis; cornstarch and whole wheat (FAO, 1992; Ekpo, 2011), but lower than the reported values for Zonocerus variegatus, vegetables, fruits and Macrotermes bellicosus (FAO, 1992).

The antioxidant vitamin analysis as shown in table 2 is rich in vitamin A (Retinol) but lower than Zonocerus variegatus, Oryctes boas, and egg (Ekpo, 2011). Vitamin A is found mainly in animal materials and acts as an antioxidant by neutralizing free radicals (Sies, 1993). Other functions are: it improves vision, plays a major role in cell differentiation, essential in embryonic development, helps in immune function by maintaining the integrity and functions of the skin and mucosal cells that functions as a barrier and forms the body's first line of defense against infections and its deficiency leads to night blindness, failure of normal bone and tooth development in children (Shils and Young, 1990). Thus, a meal of the animal sample could serve the above functions. The vitamin $\mathrm{C}$ content of the larva in this study was lower than fruits such as citrus, apricots, pear, peaches, tomatoes, mangoes, cherries etc, and that of some insects such as Zonocerus variegatus, Oryctes boas, (Banjo etal., 2006). Vitamin C is a water-soluble vitamin and might have been lost by oxidation during preservation. It is an antioxidant and therefore neutralizes free radicals and thereby preventing cancer and other diseases associated with free radical activity. It helps in the formation of collagen which is an important constituent of skin and connective tissues. Its deficiency results to scurvy and fragile capillary walls. The presence of vitamin $\mathrm{C}$ in the sample could help to attenuate oxidative stress.

The vitamin $\mathrm{E}$ content of the larva is the lowest. It is lower than the reported values for green leafy vegetables, olive oil, soybean, nuts, avocados, carrots (FAO, 1992). Vitamin E is a fat-soluble vitamin and its Recommended Dietary Allowance (RDA) is $15 \mathrm{mg}$ per day for adult male and female and $6-11 \mathrm{mg}$ for children (Ejidala et al., 2009). Its antioxidant activity helps to prevent cancer. Other functions are: reduction of myocardial infarction, enhancement of immune functions and its deficiency results in ataxia, muscle weakness and damage to the retina of the eye (Dennert and Lotan, 1978). Deficiency of ascorbic acid is associated with pains in the joint and defect in skeletal calcification, anaemia, manifestation of scurvy haemorrhage from mucous membrane of the mouth and gastrointestinal track (Hunt et al., 1980). The presence of vitamin E (table 2) may also be beneficial for coating our cell walls with a protective layer of lipids, diminishing the aging process in our tissues (Scrimshaw et al., 1968). It may also help in reducing the negative effects of environmental pollutants and food-toxins in our bodies (Ajaiyeoba and Fadare, 2006). The quantity of vitamin A in the extract as shown in table 3 suggests it can affect some aspects of the adaptive immune response. Retinoic acid, a derivative of vitamin A, enhances cytotoxicity and T-cell proliferation (Dennert and Lotan, 1978) .Vitamin A deficiency correlates with decreased $\mathrm{T}_{\mathrm{H}} 2$-cell responses (Wiedermann et al., 1993 ). 
The mineral analysis of the larva as shown in Table 3 is rich in calcium which implies that diets based on this larva will be adequate for growing children, the aged and individuals prone to osteoporosis. It is also rich in Iron which is a component of haemoglobin, myoglobin, cytochromes, non-heme proteins (Chaney, 2006). The iron content of the larva can augment the daily requirements for iron. The larva also has a high proportion of zinc but this is lower than those reported for crabs, lobsters, beef and milk (Singh, 2004). This can help in immune function and proper functioning of the cell membranes.

\section{Conclusion}

The result of this study has confirmed the fact that Oryctes rhinoceros larva is a good source of nutrients and therefore can act as an antioxidant and augment our daily recommended dietary allowance.

Since malnutrition in developing countries has been as a result of nutrient deficiency especially proteins and minerals which may be due to high cost of foods rich in these nutrients, the larva can be supplemented in our diets to take care of this problem. Also due to its high composition of vitamin A and other antioxidant vitamins, adequate intake of the larva will help to prevent cancer and in treatment of diabetes mellitus and other diseases related to free radical and oxidative stress conditions. However, more work is needed to confirm the antioxidant activity in animal model.

\section{References}

[1]. Ajaiyeoba, E.O., and Fadare, D.A. (2006) Antimicrobial potential of extracts and fractions of the African walnut- Tetracarpidium conophorum. Afric. Jour. of Biotech. 5(22):2322-2325.

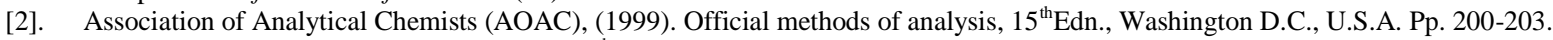

[3]. Chaney, S.G. (2006). Principles of Nutrition. $6^{\text {th }}$ Edn., John Wiley and sons, New York, vol 10 Pp 1071-1090.

[4]. Dennert, G. and Lotan, R. (1978). Effects of retinoic acid on the immune system: stimulation of T killer cell induction. Eur. J. Immunol. 8:23-29.

[5]. Ejidala, J.K., Egbogbo, O. and Anighoro, A. (2009). Proximate composition and cholesterol concentrations of Rhynchophorusphoenicis and Oryctesmonoceros larva subjected to different heat treatments.African Journal Of Biotechnology, 8 (10) : 2346-2348.

[6]. Ekpo, K.E., (2011). Effects of processing on the protein quality of four popular insects consumed in southern Nigeria. Archives of Applied Science Research, 3 (6) :.307-326.

[7]. Ekpo, K.E.andOnigbinde, A.O., (2005). Nutritional Potentials of the Larva of Rhynchophorus phoenicis, (F). Pakistan Journal of Nutrition, 4: 287-290.

[8]. FAO, (1992). Amino acid contents of food and biological data on proteins. A report of FAO/UN joint committee, Rome. 15 Pp. 251265.

[9]. Fasunwon, B,T., Banjo, A,D., Jamine, T,A., (2011). Effects of Dermestesmaculatus on the nutritional qualities of two edible Insects (Oryctes boas and Rhynchophorusphoenicis). Afrrican Journal of Food, Agriculture, Nutrition and Development, 11 (7) : $5601-5610$

[10]. Hunt, S., Goff, J.L. and Holbrook ,J. (1980). Nutririon Principles and Chemical Practices. John Wiley and Sons. New York, pp. 4952.

[11]. Mayhew, S., Penny, A, (1988). Tropical and sub-tropical foods. Macmillan, London, Pp. 212-218.

[12]. Okaraonye C.C, and Ikewuchi, J.C. (2009). Nutritional Potential of Oryctes rhinoceros larva. Pakistan Journal of Nutrition, 8 (1):3538.

[13]. Pyke, M., (1979). The science of Nutrition. John Murray Publishers Ltd., London.Pp. 150-153

[14]. Scrimshaw, N. S., Taylor, C. E. and Gordon J. E. (1968). Interactions of nutrition and infection. Monograph no. 57. World Health Organization, Geneva, Switzerland

[15]. Shils M.E.G. and Young V.R., (1990). Modern Nutrition in Health and Disease. Lea and Fabigar, Philadelphia.Pp.57-62.

[16]. Sies, H. (1993). Strategies of antioxidant defense. European Journal of Biochemistry, 215 (2) : $213-9$.

[17]. Singh S.P., (2004). Practical Manual of Biochemistry. $5^{\text {th }}$ Edition, CBS Publishers, New Delhi. Pp 80-85.

[18]. Wiedermann, U., Hanson, L.A., Kahu, H. and Dahlgren, U.I. (1993). Aberrant T-cell function in vitro and impaired T-cell dependent antibody response in vivo in vitamin A-deficient rats. Immunology. ;80:581-586.

[19]. World Health Organisation, (1992). United Nations administration committee on coordination-Subcommittee on nutrition: Overview. In $2^{\text {nd }}$ report of the world nutrition situation, 1 Pp 1-5.

Table1. Proximate composition of Oryctes rhinoceros larva

\begin{tabular}{ll}
\hline Parameter & Composition \\
\hline Moisture (\%) & $5.55 \pm 0.003$ \\
Ash (\%) & $3.01 \pm 0.005$ \\
Fat (\%) & $35.80 \pm 0.009$ \\
Protein (\%) & $33.97 \pm 0.004$ \\
Fibre (\%) & $2.33 \pm 0.005$ \\
Carbohydrate (\%) & $19.31 \pm 0.003$
\end{tabular}

Values are means \pm SEM of triplicate determinations

Table 2: mean results of some antioxidants vitamins present in Oryctes rhinoceros

\begin{tabular}{ll}
\hline Antioxidants & Mean \pm S.E (mg/100g) \\
\hline VitaminC & $0.49 \pm 0.003$ \\
VitaminA & $3.67 \pm 0.003$ \\
VitaminE & $0.42 \pm 0.003$ \\
\hline
\end{tabular}

Values are means \pm SEM of triplicate determinations 
Table 3: mean results of some vital minerals present in Oryctes rhinoceros

\begin{tabular}{ll}
\hline Minerals & Mean \pm S.E (mg/100g) \\
\hline Iron & $3.42 \pm 0.252$ \\
Zinc & $1.58 \pm 0.003$ \\
Calcium & $3.48 \pm 0.003$ \\
\hline
\end{tabular}

Values are means \pm SEM of triplicate determinations 